\title{
Viral Persistence and Chronicity in Hepatitis C Virus Infection: Role of T-Cell Apoptosis, Senescence and Exhaustion
}

\author{
Muttiah Barathan ${ }^{1}$, Rosmawati Mohamed ${ }^{2}$, Yean K. Yong ${ }^{3}$, Meganathan Kannan ${ }^{4}{ }^{(}$, \\ Jamuna Vadivelu ${ }^{1}$, Alireza Saeidi ${ }^{1}$, Marie Larsson ${ }^{5}$ and Esaki Muthu Shankar ${ }^{6, *(D)}$ \\ 1 Department of Medical Microbiology, Faculty of Medicine, University of Malaya, LembahPantai, \\ 50603 Kuala Lumpur, Malaysia; barathanmuttiah@gmail.com (M.B.); jamuna@ummc.edu.my (J.V.); \\ alirezabcsaeidi@gmail.com (A.S.) \\ 2 Department of Medicine, Faculty of Medicine, University of Malaya, 50603 LembahPantai, Kuala Lumpur, \\ Malaysia; rosmohamed@um.edu.my \\ 3 Laboratory Center, Xiamen University Malaysia, 43900 Sepang, Malaysia; yong.yeankong@gmail.com \\ 4 Division of Blood and Vascular Biology, Department of Life Sciences, Central University of Tamil \\ Nadu (CUTN), Thiruvarur 610005, India; meganathank@cutn.ac.in \\ 5 Division of Molecular Virology, Department of Clinical and Experimental Medicine, Linkoping University, \\ 58183 Linkoping, Sweden; marie.larsson@liu.se \\ 6 Division of Infection Biology and Medical Microbiology, Department of Life Sciences, \\ Central University of Tamil Nadu (CUTN), Thiruvarur 610005, India \\ * Correspondence: shankarem@cutn.ac.in
}

Received: 30 August 2018; Accepted: 9 October 2018; Published: 12 October 2018

check for updates

\begin{abstract}
Hepatitis C virus (HCV) represents a challenging global health threat to 200 million infected individuals. Clinical data suggest that only $\sim 10-15 \%$ of acutely HCV-infected individuals will achieve spontaneous viral clearance despite exuberant virus-specific immune responses, which is largely attributed to difficulties in recognizing the pathognomonic symptoms during the initial stages of exposure to the virus. Given the paucity of a suitable small animal model, it is also equally challenging to study the early phases of viral establishment. Further, the host factors contributing to $\mathrm{HCV}$ chronicity in a vast majority of acutely HCV-infected individuals largely remain unexplored. The last few years have witnessed a surge in studies showing that HCV adopts myriad mechanisms to disconcert virus-specific immune responses in the host to establish persistence, which includes, but is not limited to viral escape mutations, viral growth at privileged sites, and antagonism. Here we discuss a few hitherto poorly explained mechanisms employed by HCV that are believed to lead to chronicity in infected individuals. A better understanding of these mechanisms would aid the design of improved therapeutic targets against viral establishment in susceptible individuals.
\end{abstract}

Keywords: apoptosis; viral persistence; hepatitis C virus; immunity; chronic infection

\section{Introduction}

Hepatitis C virus (HCV), first identified in 1989 as the causative agent of hepatitis C infection, is an RNA virus belonging to the genus Hepacivirus of the Flaviviridae family [1]. The genetic information of HCV is stored in RNA, which causes the virus to mutate rapidly, accounting for the expanding diversity of $\mathrm{HCV}$ with reports suggesting that there are as many as sevengenotypes and 90 subtypes of HCV [2]. Nearly1.75 million new cases were reported in 2015 by the World Health Organization (WHO), bringing the global total of people living with HCV to 71 million [3]. HCV accounts for a majority of hepatocellular carcinoma (HCC) and liver transplantation cases worldwide. The infection 
has also been declared as a pandemic owing to its wider degree of geographic distribution and variability [4].

The very first drugs approved by the Food and Drug Administration (FDA) for HCV infection are PEGylated interferon alpha (peg-IFN) and ribavirin (RBV) that mainly target the virus rather than the host immune system [5]. The dosage and length of treatment are based on the HCV genotypes involved, for instance, HCV patients with genotypes 1, 4, 5 and 6 are treated for a period of over 48 weeks, whereas for genotypes 2 and 3 the period is only 12-24 weeks [6]. The recently designed oral regimens known as direct acting antivirals (DAA), contain a combination of several viral inhibitors that promise a shorter treatment duration with much higher cure rates, as well as fewer side effects. Nonetheless, there is a paucity of vaccines against all the variants of $\mathrm{HCV}$, largely owing to the lack of a suitable small animal model or cell culture system [7].

HCV triggers inflammation of the liver, which ranges in severity from acute illness lasting for a few weeks to life-long chronic disease, termed as chronic hepatitis $C$, also known as persistent $\mathrm{HCV}$ infection [8]. However, due to the existence of several variants of $\mathrm{HCV}$, the levels of potential persistence in the host and the susceptibility attributes to antiviral drugs may vary [9]. Epidemiological data suggest that $\sim 15 \%$ of the infected individuals spontaneously clear the virus in the first sixmonths due to robust immune responses [10-12]. The biology of HCV chronicity and the potential mechanisms that harness viral persistence are poorly understood. Certain mechanisms have been postulated based onfindings from other chronic viral infections, such as human immunodeficiency virus (HIV) and hepatitis B virus (HBV). Here, we discuss certain hitherto poorly explored aspects of mechanisms employed by HCV in order to establish persistent infection, and also the potential strategies for preventing and reversing the immunological cues to favor viral control.

\section{HCV Infection and Spontaneous Apoptosis}

Apoptosis, or programmed cell death, represents an organized mechanism of cellular suicide key to removal of worn-out cells from the body [13]. Apoptosis is regarded as a host mechanism implicated in the pathogenesis of persistent viral infections and tumorigenesis [14]. On the contrary, growing evidence suggests that viruses tend to take advantage of the host cell machinery to induce apoptosis of tissues or immune cells as a way to delay virus-specific immune responses eventually leading to persistent infection [15]. Researchers have evidenced that in general, viruses use death receptor along with non-receptor signaling pathways by eliciting pro-apoptotic receptors or their ligands on the cell surface of infected individuals as a means to induce cell death, and eventually persistence [16].

Studies have shown that hepatocytes undergo apoptosis via up-regulation of death-inducing ligands CD95/Fas, TNF-related apoptosis-inducing ligand (TRAIL) and tumor necrosis factor alpha (TNF- $\alpha$ ) on the cells during chronic HCV infection although the rates of apoptosis could vary between HCV genotypes [17,18]. In vitrostudies have shown that HCV structural and non-structural (core, NS4B and NS5B) proteins prompt cell death in liver cells via TNF- $\alpha$ by suppressing anti-apoptotic nuclear factor- $\mathrm{kB}$ (NF-kB) and activating stress c-Jun N-terminal kinase (JNK) pathways, leading to mitochondrial apoptosis $[19,20]$. This mechanism appears to be one reason for HCV-associated liver injury leading to liver cirrhosis and HCC during persistent HCV infection. Another study has postulated that certain HCV structural proteins could function as immunomodulators with up-regulated FasL on hepatocytes, causingactivated peripheral T-cells to undergo apoptosis via caspase 3 activation [21], eventually suppressing antiviral responses to assist viral persistence. It also appears that HCV not only infects hepatocytes but also B and T-cells, which accounts for the loss of optimal T-cell functions. Research also suggests that the augmented expression of Fas on peripheral T-cells of chronicallyinfected individuals relative to healthy controls, indicates the likely onset of T-cell apoptosis through the activation of caspase 8 and BH3 interacting-domain (Bid) death agonist precursors of death signaling in receptor-mediated pathways [22]. It is also becoming increasingly clear that the loss of $\mathrm{HCV}$-specific $\mathrm{CD} 8^{+} \mathrm{T}$-cells could delay the elimination of $\mathrm{HCV}$-infected cells and virus neutralization [12]. Meanwhile, non-receptor-mediated apoptosis involving mitochondria, where 
livers of patients with chronic HCV infections show elevated reactive oxygen species (ROS) levels suggestive of caspase activation, apoptosis and peripheral T-cell deletion, has also been described [23]. Another study has shown that HCV infection could induce hepatocyte death via a mitochondrial cell death pathway, whereby activation of caspase 3, nuclear translocation of activated caspase 3, secretion of ROS, and release of cytochrome $C$ from mitochondria were witnessed [24].

Recently we showed that several pro-apoptotic (TNF- $\alpha$, FasL and TRAIL) and anti-apoptotic (BCL2L1, BCL2L2, and MCL-1) molecules were upregulated in chronic HCV infection, suggesting the presence of cell death in immune cells via the extrinsic and intrinsic pathways [25]. We also found excessively higher levels of TRAIL expression in our chronic hepatitis $\mathrm{C}(\mathrm{CHC})$ cohort, suggesting the onset of apoptosis. Establishment of apoptosis is further strengthened by the up-regulation of Bcl-2 family members in the peripheral blood mononuclear cells (PBMCs) of chronic HCV-infected patients. The Bcl-2-regulated pathway appears to be a vital trigger behind the induction of intrinsic and extrinsic apoptosis, which synergistically regulates apoptosis. We also hypothesized that the release of intracellular ROS in PBMC cultures derived from chronic HCV-infected patients, which likely initiates specific BH3-only proteins, inactivates BCL-2-like pro-survival molecules. We also found that BCL-2-an anti-apoptotic molecule-was down-regulated in chronic HCV infection [25]. We are anticipating that the stimulation of PBMCs of chronic HCV-infected patients with native HCV proteins could further underpin the association of virus-specific immune cells with apoptosis signaling and viral persistence.

\section{Immunosenescence}

During normal human ageing, the host immune system becomes poorly functional in terms of cellular responses towards foreign antigens, leading to poor naïve T-cell turnover and increased expansion of senescent T-cell phenotypes through a series of events called immunosenescence [26,27]. Studies have shown that during normal ageing, T-cells become increasingly vulnerable to immunosenescence resulting in a poor frequency of functional naïve T-cell repertoire, increased rates of differentiation of naïve T-cells to terminally-differentiated T-cells, telomere shortening, decline in CD4/CD8 ratios and increased numbers of memory T-cells lacking CD28 co-stimulatory molecule, collectively culminating in increased rates of susceptibility to infections, autoimmune disorders, chronic inflammatory diseases and cancers [28-30]. However, it has been shown that certain chronic viral infections, especially HIV and HBV have a clear role in necessitating immunological impairment via a process known as replicative senescence [31]. The mechanism occurs due to persistent exposure of T-cells to viral proteins resulting in chronic immune activation (CIA) [32]. Replicative senescent T-cells generally tend to display poor levels of expression of co-stimulatory molecules (CD28 and CD27) as well as T-cell survival molecules (CD127) [33]. Together, these cells also have an increased expression of CD57, a biomarker of replicative senescence [27] as well as an over-expression of chronic activation markers such as CD38 and HLA-DR [33]. Others have reported that the frequencies of CD28 ${ }^{+} \mathrm{CD} 57^{+}$ T-cells were higher among HIV-infected individuals relative to HIV seronegative individuals [34], which could be linked to increased resistance to apoptosis and poor rates of proliferation of $\mathrm{CD} 8^{+}$ T-cells in HIV infection [35]. Subsequent work on HIV also points to the increased rates of recruitment of intermediately-differentiated $\mathrm{CD} 4^{+}$T-cell subsets $\left(\mathrm{CD} 28^{+} \mathrm{CD} 27^{-}\right)$, suggesting the onset of immunosenescence [36]. The importance of CD127 expression on T-cells for survival and cytokine responses, especially during chronic HIV infection, has also been recommended [37]. Others have also postulated that HLA-DR expression on $\mathrm{CD}^{+}$T-cells is suggestive of excessive CIA $[38,39]$. Elevated levels of $\mathrm{CD} 4^{+} \mathrm{CD} 28^{-}$T-cells co-expressing CD57 is suggestive of an expansion of senescent T-cells in chronic HBV infection [40]. Interestingly, a similar phenomenon has also been observed among chronic HCV-infected patients where higher proportions of effector senescent $\mathrm{CD} 8^{+} \mathrm{CD} 57^{+}$ T-cells were seen, which also appears to be markedly higher in liver cirrhosis [41]. Meanwhile, P16 ${ }^{\text {INK4a }}$, a tumor suppressor protein, which is also regarded as an aging marker has been found to be elevated 
among individuals infected with and co-infected with HIV/HCV suggesting the likely role of immune aging during chronic $\mathrm{HCV}$ infection, which likely facilitates $\mathrm{HCV}$ persistence [42].

We have found that there is a paucity of knowledge on the potential role of immunosenescence, especially on the phenotypes of senescent T-cells in chronic HCV infection. Hence, we studied senescent T-cell phenotypes potentially associated with exhaustion in HCV-specific and non-specific T-cells, and also involving only individuals $<53$ years to avoid potential false-positive results [43]. In our study, $\mathrm{HCV}$-specific $\mathrm{CD} 4^{+}$and $\mathrm{CD} 8^{+} \mathrm{T}$-cells from chronic $\mathrm{HCV}$-infected individuals showed a relatively increased expression of HLA-DR and CD38 as compared with T-cells derived from uninfected healthy controls. In addition, we found a clear up-regulation of CD57 on HCV-specific T-cells, which could likely be a physiological response to persistent antigenic exposure during chronic $\mathrm{HCV}$ infection and immune activation. The $\mathrm{CD} 4^{+}$and $\mathrm{CD} 8^{+} \mathrm{T}$-cells from $\mathrm{HCV}$-infected individuals showed a significant increase of late-differentiated T-cells, and reduced expression of co-stimulatory receptors (CD28 and CD27) as suggestive of immunosenescence [43]. The two co-stimulatory molecules, CD27 and CD28, are also associated with T-cellproliferation and are classical modulators of T-cell functions [44]. Our study also showed that expression of CD127 in T-cells of individuals with chronic $\mathrm{HCV}$ was dramatically reduced as compared with uninfected controls, suggesting that the function of T-cell subsets in activation, balance, differentiation, and survival could have been impaired in chronic HCV infection [45]. Further studies may be warranted to further elucidate the association of virus-specific T-cell senescence with functional responses in chronic HCV infection.

\section{Immune Exhaustion}

During viral infection, antigen presenting cells (APCs) such as dendritic cells will present virus derived peptide antigens to naïve CD4 ${ }^{+}$T-cells, which in turn will produce IL-2, IFN- $\gamma$ and TNF- $\alpha$ following activation. This helps the short-lived cytotoxic T lymphocytes (CTLs) to differentiate into memory and effector $\mathrm{CD}^{+}{ }^{+} \mathrm{T}$-cells, culminating in the killing of viral-infected cells by secreting perforin and granzyme [46,47]. However, there is a completely contrasting phenomenon termed T-cell exhaustion, whereby the functions of both T-cell subsets in some viral infected patients will be impaired while causing a chronic inflammatory state as well as repeated stimulation of T-cells [48]. T-cell exhaustion was first described in the murine chronic lymphocytic choriomeningitis virus (LCMV) clone 13 model 49, where the phenomenon could eventually repress protective humoral as well as cell-mediated immune responses [48-50] towards viral infected cells by exhibiting sub-optimal proliferative abilities and cytokine production. Researchers have proposed that T-cell exhaustion frequently occurs in suppressive tumor microenvironments [51]. Another important hallmark of T-cell exhaustion of $\mathrm{CD}^{+}$and $\mathrm{CD}^{+} \mathrm{T}$-cells is the up-regulation of inhibitory molecules/negative immune checkpoints that bind to their cognate ligands expressed on APCs during infection with adenovirus, HIV, HBV and HCV [52]. Exhausted T-cells express a group of co-inhibitory molecules (PD-1, TIM-3, CTLA-4, LAG-3, 2B4, BTLA and TRAIL) and reveal distinctive patterns of cytokines including anti-inflammatory, as well as pro-inflammatory cytokines (IL-2, TNF- $\alpha$, I L-10 and TGF- $\beta$ ), besides transcriptional repressors, BLIMP-1 and FOXP3 [53]. A recent study has concisely shown that T-cell exhaustion is a part of the natural history of chronic HCV infection [54].

The seemingly very first study on the expression of exhaustion markers in HCV infection demonstrated that PD-1 expression on HCV-specific T-cells was relatively high during acute infection and a large part of the cells were shown to express PD-1 in chronic stages of HCV infection although this was irrespective of the clinical outcome of HCV disease $[55,56]$. In another study, researchers demonstrated that T-cells in the spleen of HCV-infected patients with cirrhosis expressed higher level of PD-1 and TIM-3, predominantly in the effector memory subpopulation [54]. It has also been shown that these markers were higher on T-cells derived from the spleen as compared with peripheral blood [54].Interestingly, markers of exhaustion were reduced in splenic CD8 ${ }^{+}$T-cells and APCs after the HCV-infected patients with cirrhosis underwent splenectomy, suggesting that splenic T-cells may have a role in controlling HCV [54,57]. Meanwhile, it has also been shown that high levels of PD-1 on 
peripheral CD8 ${ }^{+}$T-cells of chronically-infected $\mathrm{HCV}$ patients correlated with higher viral loads [58], suggesting that PD-1 may have a likely role in CD8 ${ }^{+} \mathrm{T}$-cell dysfunction causing viral persistence. Another study on T-cell exhaustion in chronic HCV infection suggested that T-cells undergo rapid exhaustion with sequential loss of IL-2 production, proliferation and IFN- $\gamma$ production $[59,60]$, and increased expression of TIM-3, PD-1 and CTLA-4 [61] immediately following acute infection and persisting for a longer duration thereafter. When we compared the expression of co-inhibitory receptors and secretion of Th1/Th2/Th17 cytokines in T-cell cultures derived from chronic HCV patients and healthy controls, we found that $\mathrm{HCV}$ peptide activated $\mathrm{CD} 4^{+} \mathrm{T}$-cells of chronic $\mathrm{HCV}$ patients expressed higher levels of PD-1 while $\mathrm{CD}^{+}$T-cells had expressed significant levels of TIM-3. CTLA-4 was seen to be expressed equally on both T-cell subsets [62]. In addition, secretion of IL-10 and TGF- $\beta 1$ in T-cell cultures of chronic HCV patients were significantly increased, which are classically known to inhibit virus-specific T-cell expansion, cytokine production, and interfere with Th1/Th2 cell differentiation [63]. We proposed that accumulation of exhausted $\mathrm{HCV}$-specific $\mathrm{CD} 8^{+}$and $\mathrm{CD} 4^{+} \mathrm{T}$-cell subsets during chronic $\mathrm{HCV}$ infection results in considerable loss of protective functional immune responses likely contributing to HCV persistence [62].

\section{Does Loss of MAIT Cells Contribute to HCV Persistence?}

Specialized, innate-like T-cells with antimicrobial properties called mucosal-associated invariant $\mathrm{T}$ (MAIT) cells, represent an evolutionarily conserved $\alpha \beta$ T-cell subset in humans, and are found in copious levels in the systemic circulation accounting for $\sim 1-8 \%$ of the total T-cell pool of healthy adults [64]. MAIT cells can also be seen in lung and liver tissues ( $50 \%$ of liver T-cells). MAIT cells express an invariable TCR- $\alpha$ chain (V $\alpha 19-\mathrm{J} \alpha 33$ in mice and $\mathrm{V} \alpha 7.2-\mathrm{J} \alpha 33$ in human) together with a limited number of TCR- $\beta$ chains (V $\beta 2$ (TRBV20) and V $\beta 13$ (TRBV6)) in humans and (V $\beta 6$ and V $\beta 8$ ) chains in mice [65]. MAIT cells share phenotypic resemblance with invariant natural killer T-cells (iNKT) and express high levels of IL-12R $\beta 2$, IL-18R $\alpha$ and CD161 together with the semi-invariant $\mathrm{V} \alpha 7.2$ segment [66]. The cells are readily activated by IL-12 and IL-18 along with some foreign antigens, usually microbe-derived vitamin B metabolites, which are presented by monomorphic MHC-I-like related protein (MR1) with the help of co-stimulatory molecules, CD80 or CD86, although MAIT cells are not part of cell-mediated immune responses [67,68]. Upon activation, MAIT cells tend to secrete a wide range of cytokines (IL-4, IL-5, IL-10, IFN- $\gamma$, TNF- $\alpha$, IL-17 and IL-22) or release perforin as well as granzymes that could kill microbe-infected cells [69-72]. Several studies have proposed that MAIT cells can be associated with a number of conditions, including bacterial infections, inflammation-related diseases such as multiple sclerosis, psoriasis, allergy, autoimmune diseases and cancer $[73,74]$. Recent studies have demonstrated that although MAIT cells play a key role against viral infections, they do not directly recognize virally-infected cells.However, a cocktail of several innate cytokines (IL-18, IL-12, IL-15 and IFN- $\alpha$ ) released from infected cells stimulate MAIT cells [75]. Researchers have shown that MAIT cells are severely diminished during chronic HCV infection, and represent exhausted and immune-activated phenotypes. In addition, MAIT cell populations reconstitute poorly in patients despite successful HCV clearance [76]. Another study has shown a decrease in the frequencies of $\mathrm{CD} 161^{++} \mathrm{V} \alpha 7.2^{+} \mathrm{T}$-cells in the peripheral blood of HIV/HCV co-infected patients [77]. Interestingly, others showed that although anti-viral therapy initiated in patients helps to increase the frequencies of MAIT cells in liver, it did not do so in the peripheral blood [78]. In one of our recent investigations, we found that MAIT cells in chronic HCV patients express high levels of CD57 besides PD-1, CD38 and HLA-DR. We postulated that peripheral MAIT cells undergoing exhaustion and senescence due to repeated activation of cells during chronic HCV infection could result in diminished innate defense attributes likely contributing to viral persistence and HCV disease progression [43]. 


\section{Conclusions}

In this review we have presented several investigations on factors causing $\mathrm{HCV}$ persistence in humans. Further, several recent investigations hint at the role of microRNA in HCV disease pathogenesis [79], for instance miR-146a-5p has been proposed to promote HCV infection through metabolic pathways associated with HCV-induced liver disease progression [80]. Meanwhile, miR-122 has been proposed to play a role in delaying virus-specific immune responses leading to progression of HCV malignancy [81]. Although several investigations have been conducted on apoptosis of activated immune cells through extrinsic and intrinsic apoptotic pathways, further studies may be paramount to improve understanding of the additional roles of co-inhibitory receptors in T-cell apoptosis other than in T-cell exhaustion. Furthermore, future studies should be aimed at addressing the role of the tissue-homing abilities of MAIT cells during viral infections. Studies should also emphasize how these mechanisms work in the context of phenotypic and functional immune cells during the course of acute and chronic infections. Lastly, the development of clinical immunotherapeutic agents such as dual blockade of co-inhibitory receptor pathways to overcome $\mathrm{HCV}$-specific CD4 ${ }^{+}$and $\mathrm{CD}^{+}{ }^{+}$-cells along with MAIT cell exhaustion in chronic HCV infection, is an area that requires in-depth investigation.

Author Contributions: All authors contributed to the contents of the manuscript. E.M.S. provided supervision and financial support.

Funding: This work was supported by a grant from the High Impact Research (HIR), University of Malaya (UM.C.625/1/HIR/139), to Esaki M Shankar. MuttiahBarathan was supported by the University Malaya Fellowship Scheme grant FG019-17AFR. Marie Larsson is supported by Grant No. AI52731 from the Swedish Research Council, the Swedish Physicians Against AIDS Research Foundation, the Swedish International Development Cooperation Agency; SIDA SARC, VINNMER for Vinnova, Linkoping University Hospital Research Fund; CALF; and the Swedish Society of Medicine (SvenskaLakaresallskapet).

Acknowledgments: The authors wish to thank VanithaMariappan for the helpful discussions.

Conflicts of Interest: The authors declare no conflicts of interest.

\section{References}

1. Pfaender, S.; Brown, R.J.; Pietschmann, T.; Steinmann, E. Natural reservoirs for homologs of hepatitis C virus. Emerg. Microbes Infect. 2014, 3, e21. [CrossRef] [PubMed]

2. Li, H.C.; Lo, S.Y. Hepatitis C virus: Virology, diagnosis and treatment. World J. Hepatol. 2015, 7, 1377-1389. [CrossRef] [PubMed]

3. Pinter, M.; Trauner, M.; Peck-Radosavljevic, M.; Sieghart, W. Cancer and liver cirrhosis: Implications on prognosis and management. ESMO Open 2016, 1, e000042. [CrossRef] [PubMed]

4. Khan, A.A.; Ahmad, H.; Saif, N.; Idrees, M.; Bajwa, M.A. Frequency distribution of hepatitis in three districts of Hazara division. Asian J. Med. Sci. 2010, 2, 37-39.

5. Palumbo, E. Pegylated interferon and ribavirin treatment for hepatitis $\mathrm{C}$ virus infection. Ther. Adv. Chronic Dis. 2011, 2, 39-45. [CrossRef] [PubMed]

6. Ghany, M.G.; Strader, D.B.; Thomas, D.L.; Seeff, L.B. American Association for the Study of Liver Diseases. Diagnosis, management, and treatment of hepatitis C: An update. Hepatology 2009, 49, 1335-1374. [CrossRef] [PubMed]

7. Scheel, T.K.H.; Rice, C.M. Understanding the hepatitis C virus life cycle paves the way for highly effective therapies. Nat. Med. 2013, 19, 837-849. [CrossRef] [PubMed]

8. Park, S.H.; Rehermann, B. Immune responses to HCV and other hepatitis viruses. Immunity 2014, 40, 13-24. [CrossRef] [PubMed]

9. Messina, J.P.; Humphreys, I.; Flaxman, A.; Brown, A.; Cooke, G.S.; Pybus, O.G.; Barnes, E. Global distribution and prevalence of hepatitis $C$ virus genotypes. Hepatology 2015, 61, 77-87. [CrossRef] [PubMed]

10. Barrett, S.; Sweeney, M.; Crowe, J. Host immune responses in hepatitis C virus clearance. Eur. J. Gastroenterol. Hepatol. 2005, 17, 1089-1097. [CrossRef] [PubMed]

11. Koziel, M.J. Cellular immune responses against hepatitis C virus. Clin. Infect. Dis. 2005, 41, S25-S31. [CrossRef] [PubMed] 
12. Larrubia, J.R.; Moreno-Cubero, E.; Lokhande, M.U.; García-Garzón, S.; Lázaro, A.; Miquel, J.; Perna, C.; Sanz-de-Villalobos, E. Adaptive immune response during hepatitis $\mathrm{C}$ virus infection. World J. Gastroenterol. 2014, 20, 3418-3430. [CrossRef] [PubMed]

13. Elmore, S. Apoptosis: A review of programmed cell death. Toxicol. Pathol. 2007, 35, 495-516. [CrossRef] [PubMed]

14. Barber, G.N. Host defense, viruses and apoptosis. Cell Death Differ. 2001, 8, 113-126. [CrossRef] [PubMed]

15. Iannello, A.; Debbeche, O.; Martin, E.; Attalah, L.H.; Samarani, S.; Ahmad, A. Viral strategies for evading antiviral cellular immune responses of the host. J. Leukoc. Biol. 2006, 79, 16-35. [CrossRef] [PubMed]

16. Oldstone, M.B.A. Viral persistence: Parameters, mechanisms and future predictions. Virology 2006, 344, 111-118. [CrossRef] [PubMed]

17. Mundt, B.; Kühnel, F.; Zender, L.; Paul, Y.; Tillmann, H.; Trautwein, C.; Manns, M.P.; Kubicka, S. Involvement of TRAIL and its receptors in viral hepatitis. FASEB J. 2003, 17, 94-96. [CrossRef] [PubMed]

18. Silberstein, E.; Ulitzky, L.; Lima, L.A.; Cehan, N.; Teixeira-Carvalho, A.; Roingeard, P.; Taylor, D.R. HCV-mediated apoptosis of hepatocytes in culture and viral pathogenesis. PLoS ONE 2016, 11, e0155708. [CrossRef] [PubMed]

19. Park, M.S.; Kim, S.; Patel, J.; Hajdu, C.H.; Do, R.K.; Mannelli, L.; Babb, J.S.; Taouli, B. Hepatocellular carcinoma: Detection with diffusion-weighted versus contrast-enhanced magnetic resonance imaging in pretransplant patients. Hepatology 2012, 56, 140-148. [CrossRef] [PubMed]

20. Hoshida, Y.; Fuchs, B.C.; Bardeesy, N.; Baumert, T.F.; Chung, R.T. Pathogenesis and prevention of hepatitis C virus-induced hepatocellular carcinoma. J. Hepatol. 2014, 61, S79-S90. [CrossRef] [PubMed]

21. Iken, K.; Huang, L.; Bekele, H.; Schmidt, E.V.; Koziel, M.J. Apoptosis of activated CD4 ${ }^{+}$and CD8 ${ }^{+}$T cells is enhanced by co-culture with hepatocytes expressing hepatitis $\mathrm{C}$ virus (HCV) structural proteins through FasL induction. Virology 2006, 346, 363-372. [CrossRef] [PubMed]

22. Toubi, E.; Kessel, A.; Goldstein, L.; Slobodin, G.; Sabo, E.; Shmuel, Z.; Zuckerman, E. Enhanced peripheral T-cell apoptosis in chronic hepatitis $C$ virus infection: Association with liver disease severity. J. Hepatol. 2001, 35, 774-780. [CrossRef]

23. Muriel, P. Role of free radicals in liver diseases. Hepatol. Int. 2009, 3, 526-536. [CrossRef] [PubMed]

24. Eguchi, A.; Wree, A.; Feldstein, A.E. Biomarkers of liver cell death. J. Hepatol. 2014, 60, 1063-1074. [CrossRef] [PubMed]

25. Barathan, M.; Gopal, K.; Mohamed, R.; Ellegård, R.; Saeidi, A.; Vadivelu, J.; Ansari, A.W.; Rothan, H.A.; Ravishankar Ram, M.; Zandi, K.; et al. Chronic hepatitis C virus infection triggers spontaneous differential expression of biosignatures associated with $\mathrm{T}$ cell exhaustion and apoptosis signaling in peripheral blood mononucleocytes. Apoptosis 2015, 20, 466-480. [CrossRef] [PubMed]

26. Derhovanessian, E.; Solana, R.; Larbi, A.; Pawelec, G. Immunity, ageing and cancer. Immun. Ageing 2008, 5, 11. [CrossRef] [PubMed]

27. Chou, J.P.; Effros, R.B. T cell replicative senescence in human aging. Curr. Pharm. Des. 2013, 19, 1680-1698. [PubMed]

28. Strioga, M.; Pasukoniene, V.; Characiejus, D. CD8 ${ }^{+} \mathrm{CD} 28^{-}$and CD8 ${ }^{+} \mathrm{CD} 57^{+} \mathrm{T}$ cells and their role in health and disease. Immunology 2011, 134, 17-32. [CrossRef] [PubMed]

29. Effros, R.B. The silent war of CMV in aging and HIV infection. Mech. Ageing Dev. 2016, 158, 46-52. [CrossRef] [PubMed]

30. Janković, V.; Messaoudi, I.; Nikolich-Zugich, J. Phenotypic and functional T-cell aging in rhesus macaques (Macacamulatta): Differential behavior of CD4 and CD8 subsets. Blood 2003, 102, 3244-3251. [CrossRef] [PubMed]

31. Maue, A.C.; Yager, E.J.; Swain, S.L.; Woodland, D.L.; Blackman, M.A.; Haynes, L. T-cell immunosenescence: Lessons learned from mouse models of aging. Trends Immunol. 2009, 30, 301-305. [CrossRef] [PubMed]

32. Fülöp, T.; Larbi, A.; Pawelec, G. Human T cell aging and the impact of persistent viral infections. Front. Immunol. 2013, 4, 271. [CrossRef] [PubMed]

33. Borkow, G.; Bentwich, Z. Chronic immune activation associated with chronic helminthic and human immunodeficiency virus infections: Role of hyporesponsiveness and anergy. Clin. Microbiol. Rev. 2004, 17, 1012-1030. [CrossRef] [PubMed] 
34. Palmer, B.E.; Blyveis, N.; Fontenot, A.P.; Wilson, C.C. Functional and phenotypic characterization of $\mathrm{CD}^{2}{ }^{+} \mathrm{CD} 4^{+} \mathrm{T}$ cells and their association with HIV-1-induced T cell dysfunction. J. Immunol. 2005, 175, 8415-8423. [CrossRef] [PubMed]

35. Petrovas, C.; Chaon, B.; Ambrozak, D.R.; Price, D.A.; Melenhorst, J.J.; Hill, B.J.; Geldmacher, C.; Casazza, J.P.; Chattopadhyay, P.K.; Roederer, M.; et al. Differential association of programmed death-1 and CD57 with ex vivo survival of $\mathrm{CD}^{+} \mathrm{T}$ cells in HIV infection. J. Immunol. 2009, 183, 1120-1132. [CrossRef] [PubMed]

36. Saeidi, A.; Chong, Y.K.; Yong, Y.K.; Tan, H.Y.; Barathan, M.; Rajarajeswaran, J.; Sabet, N.S.; Sekaran, S.D.; Ponnampalavanar, S.; Che, K.F.; et al. Concurrent loss of co-stimulatory molecules and functional cytokine secretion attributes leads to proliferative senescence of $\mathrm{CD}^{+} \mathrm{T}$ cells in HIV/TB co-infection. Cell. Immunol. 2015, 297, 19-32. [CrossRef] [PubMed]

37. Sabbaj, S.; Heath, S.L.; Bansal, A.; Vohra, S.; Kilby, J.M.; Zajac, A.J.; Goepfert, P.A. Functionally competent antigen-specific CD127 (hi) memory CD8 ${ }^{+} \mathrm{T}$ cells are preserved only in HIV-infected individuals receiving early treatment. J. Infect. Dis. 2007, 195, 108-117. [CrossRef] [PubMed]

38. Deeks, S.G.; Kitchen, C.M.; Liu, L.; Guo, H.; Gascon, R.; Narváez, A.B.; Hunt, P.; Martin, J.N.; Kahn, J.O.; Levy, J.; et al. Immune activation set point during early HIV infection predicts subsequent CD4 ${ }^{+} \mathrm{T}_{\text {-cell }}$ changes independent of viral load. Blood 2004, 104, 942-947. [CrossRef] [PubMed]

39. Chou, J.P.; Ramirez, C.M.; Wu, J.E.; Effros, R.B. Accelerated aging in HIV/AIDS: Novel biomarkers of senescent human CD8 ${ }^{+}$T cells. PLoS ONE 2013, 8, e64702. [CrossRef] [PubMed]

40. Maly, K.; Schirmer, M. The story of CD4+ CD28- T cells revisited: Solved or still ongoing? J. Immunol. Res. 2015, 2015, 348746. [PubMed]

41. Focosi, D.; Bestagno, M.; Burrone, O.; Petrini, M. CD57 ${ }^{+}$T lymphocytes and functional immune deficiency. J. Leukoc. Biol. 2010, 87, 107-116. [CrossRef] [PubMed]

42. Ripa, M.; Chiappetta, S.; Tambussi, G. Immunosenescence and hurdles in the clinical management of older HIV-patients. Virulence 2017, 8, 508-528. [CrossRef] [PubMed]

43. Barathan, M.; Mohamed, R.; Vadivelu, J.; Chang, L.Y.; Saeidi, A.; Yong, Y.K.; Ravishankar Ram, M.; Gopal, K.; Velu, V.; Larsson, M.; et al. Peripheral loss of $C D 8^{+} \mathrm{CD} 161^{++} \mathrm{TCRV} \alpha 7 \cdot 2^{+}$mucosal-associated invariant T cells in chronic hepatitis C virus-infected patients. Eur. J. Clin. Investig. 2016, 46, 170-180. [CrossRef] [PubMed]

44. Luciano, A.A.; Lederman, M.M.; Valentin-Torres, A.; Bazdar, D.A.; Sieg, S.F. Impaired induction of CD27 and CD28 predicts naive CD4 T cell proliferation defects in HIV disease. J. Immunol. 2007, 179, 3543-3549. [CrossRef] [PubMed]

45. Golden-Mason, L.; Burton, J.R., Jr.; Castelblanco, N.; Klarquist, J.; Benlloch, S.; Wang, C.; Rosen, H.R. Loss of IL-7 receptor alpha-chain (CD127) expression in acute HCV infection associated with viral persistence. Hepatology 2006, 44, 1098-1109. [CrossRef] [PubMed]

46. Racanelli, V.; Leone, P.; Grakoui, A. A spatial view of the CD8 ${ }^{+}$T-cell response: The case of, H.C.V. Rev. Med. Virol. 2011, 21, 347-357. [CrossRef] [PubMed]

47. Bengsch, B.; Martin, B.; Thimme, R. Restoration of HBV-specific CD8 ${ }^{+} \mathrm{T}$ cell function by PD-1 blockade in inactive carrier patients is linked to T cell differentiation. J. Hepatol. 2014, 61, 1212-1219. [CrossRef] [PubMed]

48. Bucks, C.M.; Norton, J.A.; Boesteanu, A.C.; Mueller, Y.M.; Katsikis, P.D. Chronic antigen stimulation alone is sufficient to drive CD8 ${ }^{+}$T cell exhaustion. J. Immunol. 2009, 182, 6697-6708. [CrossRef] [PubMed]

49. Wherry, E.J.; Ha, S.J.; Kaech, S.M.; Haining, W.N.; Sarkar, S.; Kalia, V.; Subramaniam, S.; Blattman, J.N.; Barber, D.L.; Ahmed, R. Molecular signature of $\mathrm{CD}^{+} \mathrm{T}$ cell exhaustion during chronic viral infection. Immunity 2007, 27, 670-684. [CrossRef] [PubMed]

50. Jelley-Gibbs, D.M.; Dibble, J.P.; Filipson, S.; Haynes, L.; Kemp, R.A.; Swain, S.L. Repeated stimulation of CD4 effector T cells can limit their protective function. J. Exp. Med. 2005, 201, 1101-1112. [CrossRef] [PubMed]

51. Pauken, K.E.; Wherry, E.J. Overcoming T cell exhaustion in infection and cancer. Trends Immunol. 2015, 36, 265-276. [CrossRef] [PubMed]

52. Okoye, I.S.; Houghton, M.; Tyrrell, L.; Barakat, K.; Elahi, S. Coinhibitory receptor expression and immune checkpoint blockade: Maintaining a balance in $\mathrm{CD} 8^{+} \mathrm{T}$ cell responses to chronic viral infections and cancer. Front. Immunol. 2017, 8, 1215. [CrossRef] [PubMed]

53. Schietinger, A.; Greenberg, P.D. Tolerance and exhaustion: Defining mechanisms of T cell dysfunction. Trends Immunol. 2014, 35, 51-60. [CrossRef] [PubMed] 
54. Sumida, Y.; Niki, E.; Naito, Y.; Yoshikawa, T. Involvement of free radicals and oxidative stress in NAFLD/NASH. Free Radic. Res. 2013, 47, 869-880. [CrossRef] [PubMed]

55. Urbani, S.; Amadei, B.; Tola, D.; Massari, M.; Schivazappa, S.; Missale, G. Ferrari CPD-1 expression in acute hepatitis C virus (HCV) infection is associated with HCV-specific CD8 exhaustion. J. Virol. 2006, 80, 11398-11403. [CrossRef] [PubMed]

56. Kasprowicz, V.; Schulze ZurWiesch, J.; Kuntzen, T.; Nolan, B.E.; Longworth, S.; Berical, A.; Blum, J.; McMahon, C.; Reyor, L.L.; Elias, N.; et al. High level of PD-1 expression on hepatitis C virus (HCV)-specific $\mathrm{CD}^{+}$and $\mathrm{CD}^{+} \mathrm{T}$ cells during acute HCV infection, irrespective of clinical outcome. J. Virol. 2008, 82, 3154-3160. [CrossRef] [PubMed]

57. Hashimoto, N.; Shimoda, S.; Kawanaka, H.; Tsuneyama, K.; Uehara, H.; Akahoshi, T.; Kinjo, N.; Taketomi, A.; Shirabe, K.; Akashi, K.; et al. Modulation of $\mathrm{CD}^{+} \mathrm{T}$ cell responses following splenectomy in hepatitis C virus-related liver cirrhosis. Clin. Exp. Immunol. 2011, 165, 243-250. [CrossRef] [PubMed]

58. Fathy, A.A.; Khalefa, K.A.; El-Sabawy, M.M.; El Sharnoby, A.A.; Galbt, H.A. PD-1 expression on peripheral $\mathrm{CD}^{+} \mathrm{T}$ cells closely correlated with hepatitis $\mathrm{C}$ virus viral load in chronic hepatitis C patients. Menoufia Med. J. 2016, 29, 383-388.

59. Gerlach, J.T.; Diepolder, H.M.; Jung, M.C.; Gruener, N.H.; Schraut, W.W.; Zachoval, R.; Hoffmann, R.; Schirren, C.A.; Santantonio, T.; Pape, G.R. Recurrence of hepatitis C virus after loss of virus-specific CD4 ${ }^{+}$ T-cell response in acute hepatitis C. Gastroenterology 1999, 117, 933-941. [CrossRef]

60. Semmo, N.; Day, C.L.; Ward, S.M.; Lucas, M.; Harcourt, G.; Loughry, A.; Klenerman, P. Preferential loss of IL-2-secreting CD4 ${ }^{+}$T helper cells in chronic HCV infection. Hepatology 2005, 41, 1019-1028. [CrossRef] [PubMed]

61. Raziorrouh, B.; Ulsenheimer, A.; Schraut, W.; Heeg, M.; Kurktschiev, P.; Zachoval, R.; Jung, M.C.; Thimme, R.; Neumann-Haefelin, C.; Horster, S.; et al. Inhibitory molecules that regulate expansion and restoration of HCV-specific CD4 ${ }^{+} \mathrm{T}$ cells in patients with chronic infection. Gastroenterology 2011, 141, 1422-1431. [CrossRef] [PubMed]

62. Barathan, M.; Mohamed, R.; Vadivelu, J.; Chang, L.Y.; Vignesh, R.; Krishnan, J.; Sigamani, P.; Saeidi, A.; Ram, M.R.; Velu, V.; et al. CD8 ${ }^{+} \mathrm{T}$ cells of chronic HCV-infected patients express multiple negative immune checkpoints following stimulation with HCV peptides. Cell. Immunol. 2017, 313, 1-9. [CrossRef] [PubMed]

63. Rojas, J.M.; Avia, M.; Martín, V.; Sevilla, N. IL-10: A multifunctional cytokine in viral infections. J. Immunol. Res. 2017, 2017, 6104054. [CrossRef] [PubMed]

64. Kurioka, A.; Walker, L.J.; Klenerman, P.; Willberg, C.B. MAIT cells: New guardians of the liver. Clin. Transl. Immunol. 2017, 6, e132. [CrossRef] [PubMed]

65. Xiao, X.; Cai, J. Mucosal-associated invariant T cells: New insights into antigen recognition and activation. Front. Immunol. 2017, 8, 1540. [CrossRef] [PubMed]

66. Cianferoni, A. Invariant natural killer T cells. Antibodies 2014, 3, 16-36. [CrossRef]

67. Kjer-Nielsen, L.; Patel, O.; Corbett, A.J.; Le Nours, J.; Meehan, B.; Liu, L.; Bhati, M.; Chen, Z.; Kostenko, L.; Reantragoon, R.; et al. MR1 presents microbial vitamin B metabolites to MAIT cells. Nature 2012, 491, 717-723. [CrossRef] [PubMed]

68. Wakao, H.; Fujita, H. Toward the realization of cell therapy: The advent of MAIT cells from iPSCs. Cell Cycle 2013, 12, 2341-2342. [CrossRef] [PubMed]

69. Le Bourhis, L.; Martin, E.; Péguillet, I.; Guihot, A.; Froux, N.; Coré, M.; Lévy, E.; Dusseaux, M.; Meyssonnier, V.; Premel, V.; et al. Antimicrobial activity of mucosal-associated invariant T cells. Nat. Immunol. 2010, 11, 701-708. [CrossRef] [PubMed]

70. Gold, M.C.; Lewinsohn, D.M. Mucosal associated invariant T cells and the immune response to infection. Microbes Infect. 2011, 13, 742-748. [CrossRef] [PubMed]

71. Ussher, J.E.; Klenerman, P.; Willberg, C.B. Mucosal-associated invariant T-cells: New players in anti-bacterial immunity. Front. Immunol. 2014, 5, 450. [CrossRef] [PubMed]

72. Saeidi, A.; Ellegård, R.; Yong, Y.K.; Tan, H.Y.; Velu, V.; Ussher, J.E.; Larsson, M.; Shankar, E.M. Functional role of mucosal-associated invariant T cells in HIV infection. J. Leukoc. Biol. 2016, 100, 305-314. [CrossRef] [PubMed]

73. Le Bourhis, L.; Guerri, L.; Dusseaux, M.; Martin, E.; Soudais, C.; Lantz, O. Mucosal-associated invariant T cells: Unconventional development and function. Trends Immunol. 2011, 32, 212-218. [CrossRef] [PubMed] 
74. Simoni, Y.; Diana, J.; Ghazarian, L.; Beaudoin, L.; Lehuen, A. Therapeutic manipulation of natural killer (NK) T cells in autoimmunity: Are we close to reality? Clin. Exp. Immunol. 2013, 171, 8-19. [CrossRef] [PubMed]

75. van Wilgenburg, B.; Scherwitzl, I.; Hutchinson, E.C.; Leng, T.; Kurioka, A.; Kulicke, C.; de Lara, C.; Cole, S.; Vasanawathana, S.; Limpitikul, W.; et al. MAIT cells are activated during human viral infections. Nat. Commun. 2016, 7, 11653. [CrossRef] [PubMed]

76. Hengst, J.; Strunz, B.; Deterding, K.; Ljunggren, H.G.; Leeansyah, E.; Manns, M.P.; Cornberg, M.; Sandberg, J.K.; Wedemeyer, H.; Björkström, N.K. Nonreversible MAIT cell-dysfunction in chronic hepatitis C virus infection despite successful interferon-free therapy. Eur. J. Immunol. 2016, 46, 2204-2210. [CrossRef] [PubMed]

77. Spaan, M.; Hullegie, S.J.; Beudeker, B.J.; Kreefft, K.; van Oord, G.W.; Groothuismink, Z.M.; van Tilborg, M.; Rijnders, B.; de Knegt, R.J.; Claassen, M.A.; et al. Frequencies of circulating MAIT cells are diminished in chronic HCV, HIV and HCV / HIV co-infection and do not recover during therapy. PLoS ONE 2016, 11, e0159243. [CrossRef] [PubMed]

78. Bolte, F.J.; O’Keefe, A.C.; Webb, L.M.; Serti, E.; Rivera, E.; Liang, T.J.; Ghany, M.; Rehermann, B. Intra-hepatic depletion of mucosal-associated invariant $\mathrm{T}$ cells in hepatitis $\mathrm{C}$ virus-induced liver inflammation. Gastroenterology 2017, 153, 1392-1403. [CrossRef] [PubMed]

79. Shrivastava, S.; Steele, R.; Ray, R.; Ray, R.B. MicroRNAs: Role in hepatitis C virus pathogenesis. Genes Dis. 2015, 2, 35-45. [CrossRef] [PubMed]

80. Bandiera, S.; Pernot, S.; El Saghire, H.; Durand, S.C.; Thumann, C.; Crouchet, E.; Ye, T.; Fofana, I.; Oudot, M.A.; Barths, J.; et al. HCV-induced up-regulation of miR-146a-5p in hepatocytes promotes viral infection and deregulates metabolic pathways associated with liver disease pathogenesis. J. Virol. 2016, 90, 6387-6400. [CrossRef] [PubMed]

81. Bandiera, S.; Pfeffer, S.; Baumert, T.F.; Zeisel, M.B. miR-122-A key factor and therapeutic target in liver disease. J. Hepatol. 2015, 62, 448-457. [CrossRef] [PubMed]

(C) 2018 by the authors. Licensee MDPI, Basel, Switzerland. This article is an open access article distributed under the terms and conditions of the Creative Commons Attribution (CC BY) license (http://creativecommons.org/licenses/by/4.0/). 